\title{
Normatywny charakter nauk prawnych w świetle czystej teorii prawa Hansa Kelsena*
}

Tezę o normatywnym charakterze nauk prawnych Kelsen opiera na "zrozumiałym samo przez się" twierdzeniu, że przedmiotem nauki prawa są normy prawne. Ludzkie działania są przedmiotem nauki prawa tylko z uwagi na normy, tj. o ile są treścią norm. $Z$ tego punktu widzenia relacje międzyludzkie są rozpatrywane jako stosunki prawne - stosunki konstytuowane przez normy. Punkt widzenia nauki prawa określa Kelsen jako „prawny” (rechtlich), a na "prawne rozumienie” składa się ujęcie czegoś jako (a) normy prawnej, (b) jako treści normy prawnej (wymiar materialny, statyczny), (c) jako określonego przez normę prawną (wymiar formalny, dynamiczny) ${ }^{1}$. Ogólnie mówiąc, normatywny charakter nauk prawnych polega na tym, że jej przedmiotem są normy (to, co się dziać powinno) stanowiące źródło pojęć prawnych. Nauka prawa nie wyjaśnia istniejącego stanu rzeczy (tego, co jest). Przedmiot badań takiej nauki ogranicza się wyłącznie do norm prawa pozytywnego. „Powinność" w ogólnym sensie to pojęcie wyrażające zależność pewnych konsekwencji od zajścia określonych warunków (hipotetyczność normy). Normy nie muszą być wyrażone wyłącznie za pomocą hipotetycznych wypowiedzi powinnościowych, gdyż można je wyrazić za pomocą różnorodnych form lingwistycznych (np. stwierdzenie, przewidywanie, np. „X będzie karane” $)^{2}$. W interpretacji Kelsena przeciwieństwo między „powinnością” (normy) a „bytem” (fakty) jest natury „formalno-

* Referat wygłoszony na organizowanej przez Politechnikę Gdańską Międzynarodowej Konferencji Naukowej „Economy/culture/values. On the origins of social and cultural sciences. In $150^{\text {th }}$ birth anniversary of Heinrich Rickert", Gdańsk, 15-17.05.2013.

1 H. Kelsen, Reine Rechtslehre (zweite Auflage) mit einem Anhang Das Problem der Gerechtigkeit, Verlag Franz Deuticke, Wien 1967, s. 72.

2 Idem, General Theory of Law and State, przeł. A. Wedberg, Harvard University Press, Cambridge-Massachusetts 1949, s. 45. 
-logicznej”3. Uzasadnieniem powinności jest zawsze inna powinność, natomiast przyczyna uwarunkowana jest przez inną przyczynę. Rozróżnienie powyższe ma więc raczej charakter semantyczny, tj. związany ze znaczeniem danej wypowiedzi (czy stanowi ona opis, czy powinność), a nie ze strukturą rozumowania. Uzasadnieniem dla ważności pewnej normy (konkluzja), wydanej przez pewien podmiot (przesłanka mniejsza), jest inna norma wyższego rzędu (przesłanka większa). Innymi słowy: zinterpretowanie określonego faktu jako normatywnie wiążącego odsyła, zdaniem Kelsena, zawsze do innej normy.

Autor Reine Rechtslehe rozróżnia dwa rodzaje teorii prawa: statyczną i dynamiczną ${ }^{4}$. Przedmiotem teorii statycznej są "ludzkie zachowania regulowane przez normy"; poznanie nakierowane jest tu na normy ustanowione, stosowane i spełniane przez określone zachowania podmiotów. Przedmiotem teorii dynamicznej są „normy regulujące ludzkie zachowania". Poznanie nakierowane jest na określone akty ustanawiania, stosowania i spełniania prawa określone przez normy prawne. Inaczej można określić ten podział jako podział na prawo „w spoczynku” i prawo „w ruchu”. Dynamiczna teoria prawa dotyka swoistej cechy tego rodzaju systemu normatywnego, jakim jest prawo. Proces prawotwórczy jest procesem uregulowanym prawnie. Na tym, zdaniem Kelsena, polega istotna właściwość prawa, czyli regulowanie własnego ustanawiania i stosowania. Przedmiotem dynamicznej teorii prawa są normy regulujące kreacje i aplikacje prawa ${ }^{5}$.

Nauka prawa, jako nauka normatywna, nie nakazuje, nie stanowi norm, lecz opisuje je za pomocą "deskryptywnych zdań powinnościowych". Zadaniem nauki prawa jest przedstawienie prawa pewnej wspólnoty, tj. materiału wytwarzanego przez prawną zwierzchność (legal authority), poprzez prawotwórczą procedurę. Przedstawienie następuje w formie, "jeżeli pewne warunki są spełnione, wtedy nastąpić powinna określona sankcja". Należy odróżnić wyrażenia, za pomocą których nauka prawa reprezentuje prawo, od norm ustanawianych przez ustawodawcę, tj. przepisy prawne (Rechtssatz, legal rules) od norm prawnych (Rechtsnorm, legal norms) ${ }^{6}$. Normy prawne mają charakter wyrażeń preskryptywnych, natomiast przepisy prawne byłyby specyficznymi wyrażeniami deskryptywnymi ${ }^{7}$. Normy prawne nie są sądami, lecz wyrażeniami powinnościowymi - nakazuja, zezwalają i upoważ-

3 Idem, Hauptprobleme der Staatsrechtslehre entwickelt aus der Lehre vom Rechtssatz, Verlag von J. C. B. Mohr, Tübingen 1911, s. 8.

4 Idem, Reine Rechtslehre, s. 72-73.

5 Ibidem, s. 73.

6 Jest to inne rozumienie podziału „norma - przepis” niż spotykany w podręcznikach do prawoznawstwa.

7 Idem, General Theory of Law and State, s. 45. 
niają. Przepisy prawne to zdania opisujące normy, sądy hipotetyczne wiążące pewne konsekwencje z pewnymi warunkami, o funkcji prawno-poznawczej. Powyższe rozróżnienie odnosi się do odmiennych wartości opisu i przepisu, deskrypcji i preskrypcji. Zdania deskryptywne mogą być rozpatrywane jako prawdziwe lub fałszywe, normy zaś jako ważne lub nieważne. Zdania opisujące normy określonego porządku można zweryfikować poprzez odniesienie tych zdań do określonych faktów, pozwalających stwierdzić ustanowienie określonych norm ${ }^{8}$. Wyrażenia nauki prawa ujmują powinność w sensie opisowym9 Powinność stanowi swego rodzaju predykat, użycie pewnego wyrażenia powinnościowego w zdaniu opisowym. Rozróżnienie „normy” i „przepisu” nie jest zatem tożsame z rozróżnieniem „użycia” wyrażenia a „mówieniem $\mathrm{o}^{\prime \prime}$ nim $^{10}$. Reprezentacja norm prawnych poprzez przepisy prawne, dokonywana przez normatywną naukę prawa, to zarazem "mówienie o", jak i „użycie”. Czy zatem deskrypcja danej normy poprzez „użycie” jej W opisie nie jest „wtórnie preskryptywna"? W takim przypadku nauka prawa stwierdzając, że $w$ danym porządku prawnym $\mathrm{P}$ obowiązuje norma prawna N (weryfikowalny sąd), w istocie by ją "wzmacniała” (,wzmocnienie" normy poprzez jej potwierdzenie ${ }^{11}$ ).

Nauka prawa, jak twierdzi Kelsen, o ile ma stanowić odmienny rodzaj nauki, musi ujmować swój przedmiot zgodnie z inną zasadą niż zasada przyczynowości. Przedmiotem nauk prawnych nie są zdarzenia ani zachowania, lecz prawo jako porządek normatywny - społeczny fenomen ujęty jako porządek normatywny ${ }^{12}$. Zasadą umożliwiającą opis normatywnego porządku jest zasada przypisania (Zurechnung, imputation). Posiada ona analogiczną funkcję, jak zasada przyczynowości w naukach przyrodniczych. W ujęciu Kelsena podstawowa forma przepisów prawnych wygląda następująco: zgodnie z określonymi warunkami, wyznaczonymi przez porządek prawny, powinien nastąpić określony przez porządek prawny akt przymusu. Przepis prawny łączy ze sobą dwa elementy (analogia z prawem natury), lecz za pomocą innej zasady (różnica wobec praw natury). W uproszczonej formie prawo natury głosi, że ,jeżeli zachodzi A, to zachodzi B"; natomiast przepis prawny - ,jeżeli zachodzi A, to powinno zajść B (nawet, jeśli aktualnie się to nie dzieje)". Powiązanie, opisywane przez przepis prawny, ustanowione

8 Idem, Reine Rechtslehre, s. 75-76.

9 Por. Ch. Sigwart, Logik, Bd. I, Verlag von J. C. B. Mohr, Tübingen 1904, przyp. na s. 19.

10 H. L. A. Hart, Wizyta u Kelsena, w: idem, Eseje z filozofii prawa, przeł. J. Woleński, Dom wydawniczy ABC, Warszawa 2001, s. 295 i n.

11 Por. P. F. Strawson, Prawda, przeł. J. Pelc, w: Logika i jezzyk. Studia z semiotyki logicznej, wyb. i oprac. J. Pelc, PWN, Warszawa 1967.

12 H. Kelsen, Reine Rechtslehre, s. 78-79. 
jest przez prawną zwierzchność (upoważniony podmiot), tj. poprzez akt woli ustanawiający normę prawną. Stanowi zatem związek tetyczny ${ }^{13}$.

Kelsen wyróżnia trzy normatywne funkcje powinności: nakazywanie, upoważnianie i zezwalanie. Nauka prawa może wyrazić ustanowione przez normę prawną powiązanie (powiązanie dwóch rodzajów faktów) nie inaczej, niż poprzez łącznik "powinien” (w roli deontycznej zmiennej ${ }^{14}$ ) - "zgodnie z pewnym pozytywnym porządkiem prawnym pod pewnymi warunkami powinno nastąpić określone następstwo". Stwierdzenie obowiązywania normy nie jest stwierdzeniem faktu, lecz stwierdzeniem powinności. Obowiązywanie nie polega na stwierdzeniu faktu (skuteczności normy), że „coś zachodzi”, lecz że „z uwagi na określoną normę coś dziać się powinno". Z tej perspektywy nauka prawa nie opisuje związków między normami (,jjeżeli $\mathrm{A}$, to powinno być $\mathrm{B}^{\prime \prime}$ ) a faktami (,jjeżeli zachodzi A, to zachodzi B"), lecz sam stosunek (powinność $\mathrm{B}$ w przypadku A) ustanowiony przez normę. Wnioskowanie $\mathrm{z}$ tak ustanowionego stosunku o faktycznych stanach rzeczy byłoby niedorzecznością. Należy przy tym zastrzec, że nauka prawa nie opisuje dowolnego systemu normatywnego, lecz ogranicza się do norm ustanowionych poprzez określoną aktywność, które jako system (jako całość) odznaczają się skutecznością regulowania ludzkich zachowań. Skuteczność (efektywność) porządku prawnego jest warunkiem obowiązywania, a nie samym obowiązywaniem.

Wyprowadzony przez naukę prawa z normy przepis prawny jest sądem, stwierdzeniem o przedmiocie poznania - nie aprobuje, lecz opisuje, stwierdza funkcjonalne powiązanie ${ }^{15}$. Kelsen stawia nauce prawa postulat wolnego od wartościowania opisu. Opis taki miałby być niezależny od pozaprawnych wartości czy też emocjonalnej akceptacji norm. Taki opis norm prawnych formułowałby prawa w jurydycznym sensie (Rechtsgesetz, legal law). Specyficznym sensem powinności jest, zdaniem Kelsena, powiązanie przez porządek prawny pewnego warunku (delikt) z pewnym następstwem (sankcja). Sama norma prawna (Rechtsnorm) nie jest "prawem” (Gesetz) w powyższym sensie, nie opisuje bowiem funkcjonalnego powiązania, lecz jest sensem aktu, poprzez który coś jest „unormowane" (przepisane), i poprzez który funkcjonalne powiązanie pomiędzy faktami jest "pierwotnie" ustanowione. Związek ten opisywany jest następnie $w$ formie przepisów prawnych, prawa $w$ sensie jurydycznym ${ }^{16}$. Nauka prawa ujmuje normy prawne $\mathrm{w}$ formę przepisów prawnych, powiązanych w system. W tym sensie można powiedzieć, że

13 Ibidem, s. 79-80.

14 H. L. A. Hart, Doktryna Kelsena o jedności prawa, w: idem, Eseje z filozofii prawa, s. 335 .

15 H. Kelsen, Reine Rechtslehre, s. 81-84.

16 Ibidem, s. 84. 
konstytuuje swój przedmiot, co osłabiałoby ewentualny zarzut, że normatywna nauka prawa powtarzałaby tylko normy w innej formie. Jeżeli opis, dokonywany przez nauki normatywne, a ściślej jego roszczenie do prawdziwości, ma w pewnym sensie charakter „wtórnie preskryptywny" (wspominane wyżej „wzmocnienie” pewnej powinności poprzez użycie jej w zdaniu opisowym), to czy również taki opis nie byłby "prawotwórczy" (np. akt stosowania prawa poprzedza jego interpretacja, a określona interpretacja może być potwierdzona lub zaprzeczona przez naukę prawa i w ten sposób wpływać na jego stosowanie)? Wydaje się, że już sama koncepcja deskryptywnych zdań powinnościowych osłabia postulat „czystej opisowości”.

Jeżeli naukę prawa można rozpatrywać jako naukę społeczną, to, zdaniem Kelsena, stanowi ona odmianę normatywnej nauki społecznej. W odróżnieniu od przyczynowo (naturalistycznie) nastawionej nauki społecznej (psychologia, etnologia, historia, socjologia), nie opisuje ona zachowań ludzkich zgodnie z zasadą przyczynowości, lecz ujmuje je jako określone przez normy pozytywne, tj. jakie być powinny z uwagi na ustanowione normy. Zdaniem autora Reine Rechtslehre, nauka taka dotyczy rzeczywistości, lecz nie naturalnej, a społecznej. Jest nauką normatywną - nie ustanawia norm, lecz opisuje ustanowione poprzez ludzkie akty normy oraz ustanowione przez nie relacje międzyludzkie (stosunki prawne). Celem normatywnej nauki społecznej jest poznać i zrozumieć społeczeństwo jako normatywny porządek wzajemnych oddziaływań jednostek. Z tego punktu widzenia społeczeństwo jest utożsamiane z porządkiem normatywnym ${ }^{17}$. Tutaj uwidacznia się różnica między perspektywą czystej teorii prawa Kelsena a Rickertem i jego "szkołą". Autor Reine Rechtslehre twierdzi, że istotna różnica między naukami nie jest wyznaczona przez dualizm „natura - kultura”, lecz przez opozycję „nauki kauzalne (przyczynowe) - nauki normatywne”. I tak nauki o kulturze, o ile dotyczą faktów, należą do nauk kauzalnych, jeśli natomiast dotyczą wartości, to wchodzą w zakres nauk normatywnych. Nauka prawa byłaby „,w istocie” nauką normatywną (normatywny charakter stanowi o jej autonomii), natomiast historia prawa, społeczny i psychologiczny wymiar prawa należałyby do nauk kauzalnych ${ }^{18}$.

Norma prawna stanowi podstawę dla specyficznych sądów wartościujących - jurydycznych sądów wartościujących (juristic value judgments), kwalifikujących pewne zachowania jako prawne, legalne, słuszne, bezprawne, nielegalne, niesłuszne. Według Kelsena, należy ściśle rozróżnić wartości prawne, których ważność jest obiektywna, od „war-

17 Ibidem, s. 89-90.

18 Por. Idem, Die Rechtswissenschaft als Norm-oder Kulturwissenschaft, w: Die Wiener rechtstheoretische Schule, Bd. 1, Hrsg. H. R. Klecatsky, R. Marcic, H. Schambeck, Franz Steiner Verlag, Wien 2010. 
tości sprawiedliwościowych" (values of justice) o ważności subiektywnej. Jurydyczny sąd wartościujący to „stwierdzenie pozytywnej lub negatywnej relacji między pewnym zachowaniem a normą której istnienie (ważność) jest zakładane przez osobę wydającą sąd". Sąd taki posiada obiektywną ważność, ponieważ może być zweryfikowany poprzez odniesienie do faktu obowiązywania normy w ramach efektywnego porządku normatywnego (efektywność jako warunek ważności, a nie sama ważność). Inaczej jest w przypadku „wartości sprawiedliwościowych” (słuszność), bowiem sądy wydawane na ich podstawie odnoszą się do wartości postrzeganych jako ważne przez określone jednostki, a ich ważność jest do nich zrelatywizowana. Sądy takie mogą wysuwać roszczenia do obiektywności, lecz brak w ich przypadku kryterium weryfikacji obiektywnej ważności ${ }^{19}$. Można by w tym miejscu wyrazić następującą wątpliwość, otóż, Kelsen twierdzi, że roszczeniami, jakie zawierają wypowiedzi normatywnej nauki prawa, są roszczenie do prawdziwości i (wtórnie przez odniesienie do norm prawnych) roszczenie do ważności. Biorąc pod uwagę hierarchiczną strukturę prawa, norma niższego rzędu zawiera roszczenie do słuszności z uwagi na treść normy wyższego rzędu. Jeżeli dodamy do tego pewną otwartość norm prawnych na inne wartości niż ściśle prawne (klauzule generalne), to można powiedzieć, że rekonstruując normy prawne nauka prawa również będzie musiała wydawać „sądy o słuszności” z uwagi na pewne „wartości sprawiedliwościowe". Na powyższą kwestię można odpowiedzieć wskazaniem, że tego typu odesłania inkorporują „wartości sprawiedliwościowe” w system „wartości prawnych”. Jednakże przy treściowej niedookreśloności inkorporowanych „wartości sprawiedliwościowych" rekonstrukcja „zawierających je" norm prawnych będzie odznaczała się pewnym stopniem subiektywności ${ }^{20}$.

Przedmiotem normatywnej nauki prawa jest prawo jako system norm, fakty zaś tylko o tyle, o ile są determinowane przez prawo. Wyrażenia, za pomocą których nauka prawa opisuje swój przedmiot, są wyrażeniami o tym, co być powinno (deskryptywne zdania powinnościowe), a nie, co jest ${ }^{21}$. Zdaniem Kelsena, nie można przeciwstawić jej empirycznej nauce prawa, bowiem stanowi opis norm prawa pozytywnego, a nie naturalnego („,metafizycznego"). Nie należy mylić przedmiotu nauki $\mathrm{z}$ nią samą 22 . Przedmiotem nauki prawa są normy będące niejako produktem procedury prawodawczej. Normatywna nauka prawa opisuje

19 Idem, General Theory of Law and State, s. 48-49.

20 Por. też tezę R. Alexyego, że w samym pojęciu prawa tkwi roszczenie do słuszności: R. Alexy, The Argument from Injustice. A Reply to Legal Positivism, transl. B. Litschewski-Paulson and S. L. Paulson, Oxford University Press, New York 2002.

21 H. Kelsen, General Theory of Law and State, s. 162.

22 Ibidem, s. 163. 
ważne normy prawne, pod warunkiem skuteczności (faktycznego oddziaływania) porządku prawnego jako całości, co oznacza, że jej twierdzenia są weryfikowalne ${ }^{23}$. Rozdzielenie perspektywy nauki kauzalnej i normatywnej nie oznacza, że między „bytem” a "powinnością" zachodzi jakieś fundamentalne przeciwieństwo. Funkcją porządku prawnego jest pobudzanie do zachowania "przepisywanego" przez ów porządek, tj. uczynienie z norm nakazujących określone zachowanie możliwych motywów determinowania ludzkiej woli do zgodnego z nimi zachowania. Norma ma stanowić niejako „przyczynę" zgodnego z nią zachowania. $W$ tym sensie porządek prawny „włącza się w łańcuch przyczyn i skutków", na czym polega jego funkcja społeczna, czyli wpływanie na zachowania jednostek. Normatywność i przyczynowość nie wykluczają się wzajemnie, a nawet więcej - możliwość „przyczynowej skuteczności” normy prawnej stanowi o jej sensowności (np. ogólna norma „nie powinieneś umierać" jest bez sensu) ${ }^{24}$. Różnica dotyczy perspektywy, $\mathrm{z}$ jakiej normatywna nauka prawa odnosi się do swojego przedmiotu. Bada ona bowiem tylko wytwór aktów woli, sam ten akt natomiast, o ile jest treścią innego aktu woli (uwarunkowania powstania normy i jej skuteczności ujmują nauki zorientowane kauzalnie, np. historia prawa, socjologia prawa itp.). Inaczej, norma prawna N1 jest treścią pewnego aktu woli A1, akt woli A1 ma znaczenie aktu prawodawczego, o ile wynika z wyższej normy N2, która również jest treścią pewnego aktu woli A2 itd. Dlatego też kwestią szczególnie istotną dla teorii nauki prawa jako nauki normatywnej jest nie tyle kwestia weryfikowalności, co zagadnienie ważności (por. teoria normy podstawowej). Jednakże warunkiem, pod którym normatywna nauka prawa opisuje pewien system, jest jego skuteczność jako całości. Mów mi baronie, bo to dobrze brzmi...*

23 Ibid., s. 171.

24 Idem, Reine Rechtslehre, s. 97-98. 